\title{
MENGURANGI GAP PERGURUAN TINGGI DENGAN DUNIA KERJA: UPAYA PENINGKATAN KUALITAS SUMBERDAYA MANUSIA
}

\author{
Agus Zaenul Fitri \\ IAIN Tulung Agung \\ Jawa Timur, Indonesia
}

\begin{abstract}
The high capability for managing Higher Education (HE) is necessary which include adopting of modern management principles that focus on quality, continous improvement and customer satisfaction. Globalization era is competation era, so HE must based quality in any of its processed. The students of HE that still studying need a product of motivation and double communication that are; science, academic title, skill, experience, belief and good behaviour on the contex of balance. All of them need to work in workplace expected a better life in this world is systematic attempt to increase human resources quality. There are four points on education field, namely; average and opportunity of education, relevancy with development, quality and efficiency. Therefor $H E$ needs to support a certain aim to increase their level lecturer qualification with next educational level or non-degree course in order to enhance a quality of human resources resulted automatically will support a quality of education at $H E$.
\end{abstract}

Keywords: gap, education, dunia kerja, SDM

\section{Abstrak}

Kemampuan tinggi untuk mengelola Pendidikan Tinggi (PT) diperlukan. Hal itu meliputi mengadopsi prinsip-prinsip manajemen modern yang fokus pada kualitas, perbaikan terus-menerus dan kepuasan pelanggan. era globalisasi adalah era kompetisi, sehingga PT harus berdasarkan kualitas dalam setiap olahannya. Para siswa dari PT yang masih belajar membutuhkan produk motivasi dan komunikasi ganda yang; ilmu pengetahuan, gelar akademik, keterampilan, pengalaman, keyakinan dan perilaku yang baik pada contex keseimbangan. Semua dari mereka harus bekerja di tempat kerja diharapkan kehidupan yang lebih baik di dunia ini adalah upaya sistematis untuk meningkatkan kualitas sumber daya manusia. Ada empat poin di lapangan pendidikan, yaitu; peluang rata-rata dan pendidikan, relevansi dengan pembangunan, kualitas dan efisiensi. Maka PT perlu mendukung tujuan tertentu untuk meningkatkan kualifikasi dosen tingkat dengan tingkat pendidikan berikutnya atau non-gelar saja dalam rangka meningkatkan kualitas sumber daya manusia mengakibatkan otomatis akan mendukung kualitas pendidikan di PT.

Kata kunci: gap, pendidikan, dunia kerja, SDM

\section{Pendahuluan}

Peningkatan kemampuan untuk mengelola dan mengembangkan Perguruan Tinggi (PT) sudah sangat perlu dilakukan, termasuk penggunaan prinsipprinsip manajemen modern yang berorientasi pada kualitas. Bagi para pemilik dan pengelola PT, sistem manajemen mutu pada hakekatnya berinti pada continues improvement (perbaikan terus menerus) dan quality assurance (jaminan kualitas), (Burnharn, 1997:359). Bahkan untuk memastikan bahwa proses yang dilakukan adalah untuk mencapai mutu yang diharapkan dibutuhkan quality control (kendali mutu) dan inspection (pengawasan), (Burnharn, 1997:18). Lebih lanjut, menurut Deming dalam Total 
Quality Management (TQM), diperlukan TQC (Total Quality Control) dalam usaha pengendalian mutu (Heryanto, 1993:11). Free Trade Area (pasar bebas) telah menuntut dunia pendidikan khususnya PT untuk lebih cermat dalam menentukan pandangan ke depan yang didasarkan atas pertimbangan potensi, kendala, peluang, dan ancaman yang menuntutnya lebih efektif dan efisien dalam bertindak yang mencapai visi dan misi yang telah ditetapkannya.

Globalisasi adalah era persaingan mutu atau kualitas. Maka PT di era globalisasi ini harus berbasis pada mutu, bagaimana fokus PT dalam kegiatan jasa pendidikan maupun pengembangan sumber daya manusia yang memiliki keunggulan-keunggulan. Para mahasiswa yang sedang menuntut ilmu di PT sesungguhnya mengharapkan hasil ganda dari proses pendidikan dan pembelajaran yang telah dilakukan, yaitu ilmu pengetahuan, gelar, keterampilan, pengalaman, keyakinan, dan perilaku luhur serta life skill dalam arti seimbang. Semuanya itu diperlukan sebagai persiapan memasuki dunia kerja dan atau persiapan membuka lapangan kerja baru dengan mengharapkan kehidupan yang baik dan kesejahteraan lahir maupun batin.

PT sebagai wadah untuk mencetak generasi berkualitas masa depan memerlukan suatu cara pengelolaan yang berbeda dengan pengelolaan instansi nonpendidikan, karena di dalamnya terdapat orang-orang yang berilmu dan bernalar tinggi. Tanggung jawab pendidikan tidak menjadi beban pemerintah saja, namun merupakan tanggung jawab semua masyarakat. Masalah penting yang harus diperhatikan adalah bagaimana manajemen PT dikelola secara efektif, akuntabel dan tranparan, sehingga dapat dipertanggung jawabkan kepada pemerintah dan masyarakat secara umum. Peraturan-peraturan akademik dan administrasi mempunyai tata kerja membentuk suatu sistem yang harus ditaati dengan disiplin dan dedikasi semua pihak. Dengan sistem seperti ini, maka ada jaminan penuh bahwa perahu akan melaju ke arah yang sudah ditentukan kalaupun nakhodanya berganti di tengah perjalanan. Prasarana dan sarana akademik harus diciptakan sebagai landasan berpijak, di samping landasan mutu perguruan tinggi ini terutama sangat ditentukan oleh peran tenaga-tenaga pendidik dan kependidikan yang berkualitas dan terampil.

\section{Pendidikan di Perguruan Tinggi}

PT merupakan suata wahana yang diharapkan mampu mengembangkan ilmu pengetahuan dan memberi kontribusi kepada perbaikan suatu bangsa dan Negara, sehingga PT tidak hanya berupaya bagaimana menghasilkan lulusan yang baik, tetapi juga berkualitas, terampil dan siap kerja. Usaha sistematis untuk meningkatkan kualitas sumberdaya manusia (SDM) telah ditunjukkan dengan menetapkan empat kebijakan pokok dalam bidang pendidikan, yaitu: (1) Pemerataan dan kesempatan; (2) Relevansi pendidikan dengan pembangunan; (3) Kualitas pendidikan; dan (4) Efisiensi pendidikan. Khusus untuk perguruan tinggi akan lebih diutamakan membahas mengenai relevansi pendidikan dengan pembangunan yang dalam langkah pelaksanaannya dikenal dengan keterkaitan dan kesepadanan (link and match).

Keterkaitan

(link)dalampengertianketerkaitan

program pendidikan dengan kebutuhan pembangunan, sehingga terjadi kesesuaian/kecocokan (match) dalam pengertian lulusannya siap pakai untuk memenuhi kebutuhan pembangunan. 
PT yang berkualitas itu setidaknya harus mampu memenuhi kebutuhan stakeholder, berupa: (1) social need (kebutuhan masyarkat); (2) industrial needs (kebutuhan industri); dan (3) professional needs (kebutuhan profesional) (Dirjen, 2003). Oleh sebab itu, hanya dengan pengetahuan yang mendalam tentang apa yang dibutuhkan oleh pengguna jasa dan workplace tersebut, pendidikan akan dapat lebih mencapai hasil yang sesuai dengan misi dan visinya.

Upaya menciptakan keterkaitan dan kesepadanan tersebut mengacu pada Tridharma Perguruan Tinggi, yang meliputi kegiatan-kegiatan pendidikan dan pembelajaran, penelitian, dan pengabdian kepada masyarakat. Dalam Tri Dharma Pendidikan, perlu dievaluasi relevansi program dan jurusan yang ada dalam kebutuhan pembangunan, dalam arti apakah sumber daya manusia yang dihasilkan dapat diserap oleh kegiatan perekonomian dan pembangunan.

Pertama, adanya raw input dan instrumental input. Raw input merupakan peserta didik, sedangkan instrumental input terdiri dari: gedung, perpustakaan, pedoman akademik, dosen, kurikulum, metode dan lain-lain. Kedua, raw input dan instrumental input masuk dalam proses, yang ini akan memakan waktu delapan (8) semester. Ketiga, output (hasil didik) yang sesuai dengan kriteria institusi dan siap untuk masuk ke dalam persaingan sumber daya manusia. Dosen merupakan instrumen yang sangat menentukan keberhasilan proses pendidikan, karena dari dosenlah perpindahan (transfer) ilmu dilakukan kepada peserta didik. PT yang memiliki tenaga-tenaga dosen yang berkualitas akan banyak diminati oleh masyarakat. Karena itu program untuk meningkatkan kualitas para dosen adalah merupakan kewajiban yang tidak ditawar lagi pada saat ini dan di masa mendatang. Perguruan tinggi yang tidak mau mengikuti arus perkembangan perubahan sekarang dan di masa mendatang akan ditinggalkan oleh masyarakat dan cepat atau lambat akan mengalami kemunduran, yang akhirnya akan mengalami keruntuhan.

Konsep link and match harus menjadi perhatikan PT, sebab selama ini ada kesan bahwa PT selalu terlambat dalam menyiapkan/menyediakan lulusan yang siap kerja. Selain disebabkan PT yang lamban dalam merespon perubahan dan perkembangan serta percepatan arus teknologi dan informasi, juga karena selalu berubahnya standar mutu dan kualitas keahlian yang dibutuhkan oleh dunia kerja serta tuntutan industri. Menurut Thurow (1999:43), bahwa "perolehan keahlian itu memerlukan perubahan dalam proses pembelajaran, karena: (1) Keahlian yang diperlukan untuk mencapai keberhasilan akan semakin tinggi dan berubah sangat cepat, (2) Keahlian yang diperlukan sangat tergantung pada teknologi dan inovasi baru, maka banyak dari keahlian itu harus dikembangkan dan dilatih melalui pelatihan dan pekerjaan, dan (3) Kebutuhan akan keahlian itu didasarkan pada keahlian individu."

Dalam rangka mendekatkan jurang pemisah (gap) antara PT dengan dunia kerja, maka PT harus melalukan beberapa upaya, yaitu:

1. Managing self (Menata diri)

Keterampilan menata diri merupakan kompetensi dasar yang dibutuhkan dan dikembangkan oleh PT, kompetensi ini adalah prasyarat untuk mengembangkan kompetensi dan keterampilan tertentu.

\section{Communication (Komunikasi)}


Berkomunikasi merupakan landasan utama bagi peningkatan kompetensi ilmu pengetahuan umum, pengembangan nilai, dan peningkatan keahlian dalam disiplin ilmu tertentu. PT harus mampu meningkatkan komunikasi, baik secara lisan maupun tulisan agar dapat memberikan pelayanan dan pengalaman kepada para mahasiswanya.

3. Managing people and task (Menata orang dan tugas)

Pada prinsipnya, tidak ada perbedaan antara laki-laki dan perempuan dalam hal menata orang dan tugas. Dalam penelitian ditemukan bahwa semakin lama orang menduduki suatu posisi, baik di lingkungan sekolah atau pekerjan, semakin buruk pula dalam menyelesaikan pekerjaan sesuai dengan standar yang ditentukan. Keterampilan ini adalah sebuah usaha bersama yang terjadi dalam kelompok. Konsep menata orang dan tugas-tugas didasarkan pada manajemen di masa mendatang. Maka dari itu, perlu adanya pelatihan keterampilan ini secara kelompok. Pelatihan bersifat spesifik, praktis dan segera. Yang dimaksudkan pelatihan spesifik dalam arti pelatihan berhubungan secara spesifik dengan pekerjaan yang dilakukan (Ciptono, 2003:212).

4. Mobilizing innovation and change (Mengerakkan inovasi dan perubahan)

Suatu lembaga atau organisasi harus mampu beradaptasi dengan adanya perubahan yang terjadi di dunia luar, dan memberikan pengaruh terhadap perubahan itu secara inovatif. Lembaga atau organisasi akan berhasil jika menggerakkan inovasi dan perubahan yang sangat ditekankan dan dihargai. Dalam suatu lembaga penting untuk menyediakan para "inovator" yang menghasilkan ideide cemerlang. Ide-ide tersebut dapat dijadikan sebagai visi. Visi memegang peranan penting dalam TQM (Total Quality Management). Hal itu dikarenakan betapa pengaruh visi dalam menggerakkan seluruh komponenkomponen yang ada dalam organisasi atau lembaga (Murgatroy: 1994:38). Oleh karena itu, penentuan visi harus benarbenar mampu memberikan inpirasi dan motivasi kepada seluruh person pada lembaga atau organisasi.

Berikut ini, merupakan gambaran tentang bagaimana hubungan antara PT dengan dunia dan tempat kerja (workplace) 


\section{Gambar 1. Hubungan Perguruan Tinggi dengan Dunia Kerja}

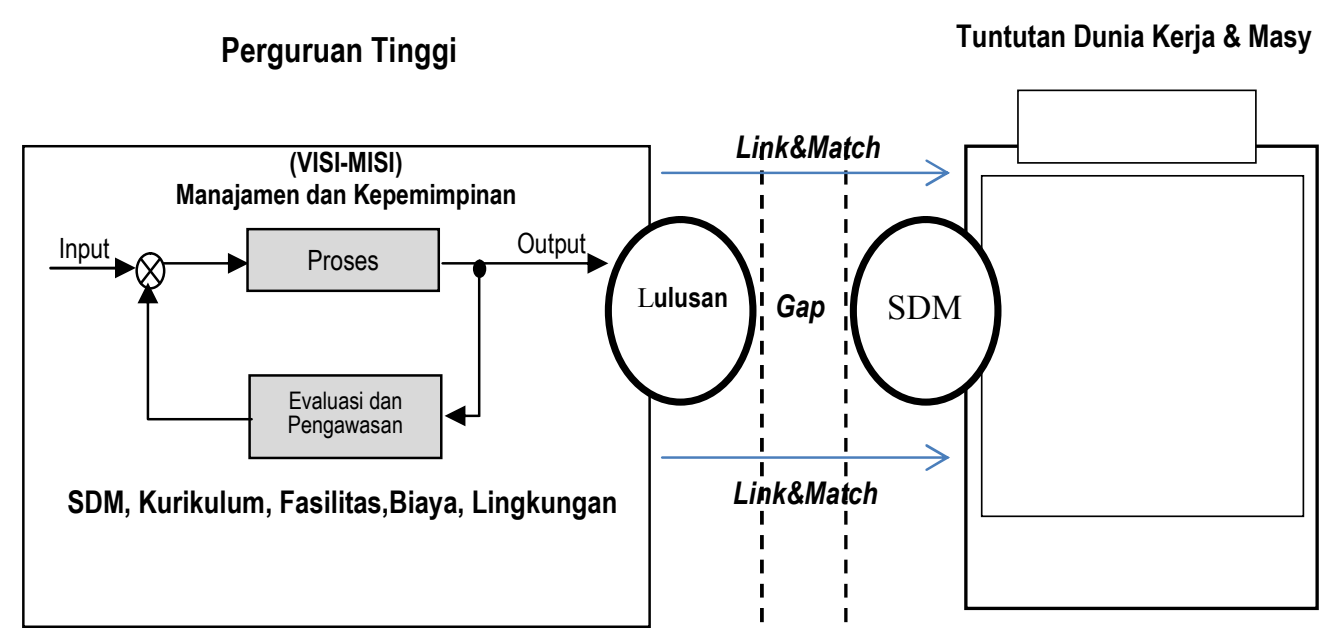

Sumber: data diolah

Hanya dengan pengetahuan yang mendalam tentang apa yang dibutuhkan oleh pengguna jasa dan workplace tersebut, pendidikan akan dapat lebih mencapai hasil sesuai dengan misi dan fungsinya. Upaya menciptakan keterkaitan dan kesepadanan tersebut mengacu pada Tri Dharma PT, yang meliputi: (1) Pendidikan dan pengajaran, (2) Penelitian, dan (3) Pengabdian kepada masyarakat. Dalam Tri Dharma, pendidikan perlu dievaluasi relevansi jurusan dan program studi yang ada dalam kebutuhan masyarakat dan dunia kerja, dalam arti apakah sumber daya manusia yang dihasilkan dapat diserap oleh kegiatan pendidikan, perekonomian, sosial-budaya, politik, industri, dan kebutuhan masyarakat lainnya.

Pertama, dikenal adanya raw-input dan instrumental input. Raw input merupakan peserta didik, sedangkan instrumental input terdiri dari: gedung, perpustakaan, pedoman akademik, dosen, kurikulum, metode, lingkungan dan lain sebagainya. Kedua, raw input dan instrumental input masuk dalam proses, yang akan memakan waktu kurang lebih delapan semester. Ketiga, Output (lulusan) yang sesuai dengan kriteria institusi dan siap untuk masuk ke dalam persaingan sumber daya manusia. Dosen merupakan instrumen yang sangat menentukan keberhasilan proses pendidikan, karena dosen harus berkualitas dan memiliki dedikasi yang tinggi untuk meningkatkan kualitas mahasiswa, karena proses pendidikan dan pembelajaran dihasilkan dari interaksi di antara mereka. PT yang memiliki tenaga-tenaga dosen yang berkualitas akan banyak diminati oleh masyarakat. Karena itu, program untuk meningkatkan kualitas para dosen merupakan kewajiban yang tidak ditawartawar lagi pada saat ini dan juga di masa mendatang. PT yang tidak mau mengikuti arus perkembangan perubahan sekarang dan di masa mendatang akan ditinggalkan oleh masyarakat dan lambat atau cepat akan mengalami kemunduran, yang akhirnya akan mati.

\section{Peningkatan Mutu Pendidikan Tinggi}

PT yang bermutu berarti menjalankan prinsip-prinsip dan nilainilai mutu yang jelas, baik mutu input, mutu proses, mutu out put maupun outcomes yang dapat dijalankan melalui implementasi sistem penjaminan mutu pendidikan. Menurut Permendikbud 
Nomor 50 tahun 2014, "bahwa yang dimaksud penjaminan mutu adalah kegiatan sistemik untuk meningkatan mutu pendidikan tinggi berencana dan berkelanjutan." Lebih lanjut juga dijelaskan bahwa: "Sistem Penjaminan Mutu Pendidikan yang selanjutnya disebut SPMP adalah Subsistem dari Sistem Pendidikan Nasional yang berfungsi utamanya meningkatkan mutu pendidikan." Untuk menjalan sistem tersebut, maka perlu membentuk LPMP (Lembaga Penjaminan Mutu Pendidikan) yang merupakan unit pelaksana teknis Departemen Pendidikan Nasional sebagaimana diatur dalam Peraturan Menteri Pendidikan Nasional Nomor 7 tahun 2007 tentang organisasi dan Tata Kerja Lembaga Penjaminan Mutu Pendidikan dan Peraturan Menteri Pendidikan Nasional Nomor 66 tahun 2008 tentang organisasi dan tata kerja lembaga penjaminan mutu pendidikan.

Jaminan mutu adalah keseluruhan aktivitas dalam berbagai bagian dari sistem untuk memastikan bahwa mutu produk atau layanan yang dihasilkan selalu konsisten sesuai dengan yang direncanakan/dijanjikan. (Tim Dosesn UGM, 2005: 5), Mutu sangat berkaitan dengan ciri khas yang diberikan dan menunjukkan kesiapan lulusan untuk bekerja sebagaimana diharapkan oleh pelanggan.

Berdasarkan gambar yang ditunjukkan sebelumnya dapat dijelaskan bahwa untuk menghasilkan mutu yang diharapkan langkah pertama yang dilakukan adalah melakukan analisis gap (gap analysis) untuk mengetahui seberapa besar jarak antara kondisi riil PT saat ini dengan visi yang diharapkan. Selanjutnya, dilakukan tindakan untuk memperbaiki kondisi berdasarkan hasil analisisgap, implementasi proses akademik, dan penilaian akhir yang dilakukan secara terus menerus. Kemudian terkait dengan tentang kompetensi lulusan PT yang bermutu setidaknya mencakup: 1) pengetahuan dan kemampuan cara berpikir; 2) keterampilan dasar, misalnya: (a) kemampuan berkomunikasi; (b) kemampuan memanfaatkan teknologi informasi; (c) kemampuan belajar mandiri; 3) ketrampilan kognitif, misalnya: (a) memahami metodologi riset; (b) kemampuan menganalisis secara tajam dan kritis; 4)keterampilan dalam bidang tertentu yang ditekuni di program studi.

Untuk mengurangi gap PT dengan dunia kerja dan tuntutan masyarakat, maka PT melalui program studi yang tersedia perlu menyesuaikan kurikulum dan kegiatan pembelajaran dengan tuntutan masyarakat. Input (calon mahasiswanya) haruslah berkualitas, tenaga pengajarnya berprestasi dan berkompetensi dalam bidangnya masing masing, proses pendidikannya berjalan secara efektif, serta sarana dan prasarananya harus memadai. Sebab itu, ada beberapa hal yang perlu diperhatikan sehubungan dengan strategi peningkatan mutu pendidikan di PT antara lain:

Pertama, mahasiswa. Untuk dapat menghasilkan produk yang baik, harus ditanam bibit-bibit yang baik. Untuk mendapatkan bibit yang baik perlu seleksi yang baik pula. Kendalanya yang dihadapi di berbagai Perguruan Tinggi yang ada di Indonesia dalam mendapatkan calon mahasiswa baru yang mempunyai kualitas baik, seringkali terbentur dengan beberapa faktor misalnya dengan "biaya yang terjangkau dan mutu terjamin" yang harus tetap dilaksanakan. Sistem seleksi yang belum mempertimbangkan segi mutu calon mahasiswa yang sesungguhnya, karena standar kelulusan untuk bisa diterima di suatu fakultas belum begitu ketat dilakukan. Hal ini akan berdampak pada mutu lulusan, sebab 
proses seleksi sangat menentukan mutu lulusan. Jika langkah awal ini sudah baik, maka sumberdaya manusia akan mudah dikembangkan (Soetjipto, 2002: 86).

Untuk dapat meningkatkan mutu pendidikan, dari calon mahasiswa harus betul-betul dapat dijaring dengan seleksi yang ketat supaya calon mahasiswa yang diterima di perguruan tinggi mempunyai standar kualitas yang baik, karena bagaimanapun mahasiswa tidak lepas dari tanggung jawab terhadap perkembangan sebuah perguruan tinggi. Di samping itu, tingkat kedisiplinan mahasiswa perlu ditingkatkan, karena melalui disiplin yang tinggi ini diharapkan mahasiswa benarbenar dapat mandiri dan bertanggung jawab terhadap dirinya sendiri dan ilmu pengetahuan yang diterimanya. Untuk menambah mutu serta kemampuan mahasiswa saat mengikuti perkuliahan di perguruan tinggi, perlu ditambah dengan kemampuan berorganisasi, sebab organisasi ini akan mampu mengembangkan pribadi mahasiswa dan menambah pengalaman guna menunjang ilmu pengetahuan yang diterimanya.

Kedua, dosen (pendidik). Dosen harus mempunyai kualifikasi yang diperlukan untuk mentransfer sekaligus mentransformasikan ilmunya kepada mahasiswa. Dengan tenaga dosen yang berkompeten dan berkualitas akan memudahkan penyampaian ilmu pengetahuan dan teknologi, sehingga apa yang disampaikan kepada mahasiswa dapat diterima dan dikembangkan sesuai dengan kemampuan mahasiswa dengan kajian bidang ilmu yang dipilihnya. Di samping itu, dosen juga harus mempunyai disiplin yang tinggi juga mempunyai rasa tanggung jawab terhadap ilmu yang diberikan kepada mahasiswa. Bagaimana mungkin dapat meningkatkan mutu pendidikan apabila dosen hanya memberikan kuliah tiga sampai empat kali pertemuan dalam setiap semesternya? Jadi dosen harus mempunyai tanggung jawab yang besar terhadap anak didiknya agar ia tidak hanya memberikan kuliah secara asal-asalan.

Tanpa ada upaya untuk meningkatkan kualitas dosen yang ada sekarang, perubahan-perubahan mendasar pada kurikulum dan metode belajar mengajar akan timpang dan bisa jadi kurang efektif. Peningkatan kualitas dosen perlu dimulai dari sistem perekrut, peningkatan kemampuan dosen, sistem penilaian terhadap kemampuan dan kinerja dosen, serta sistem peningkatan karirnya. Tentu saja upaya peningkatan kualitas dosen perlu disertai dengan peningkatan kesejahteraannya. Sertifikasi dosen dan jaminan pensiun bisa menjadi salah satu upayanya. Mengenai pengertian tentang pensiun pasal 10 UU No.8/1974 tentang pokok-pokok kepegawaian mengemukakan bahwa ialah jaminan hari tua adalah jaminan yang diberikan sebagai balas jasa terhadap pegawai yang telah mengabdi selama bertahun-tahun kepada negara. Secara umum, pensiun berarti jaminan hari tua yang diberikan sebagai balas jasa terhadap pegawai yang telah mengabdi kepada lembaga atau organisasi (Slamet, 1997:135).

Kemampuan dosen terdiri dari kemampuan dalam ilmu pengetahuan yang akan diajarkan dan teknik dalam memberikan pengajaran. Hal ini berarti peningkatan kemampuan dosen perlu dilakukan dari dua aspek, yaitu peningkatan ilmu pengetahuan di bidangnya, dan kemampuan atau keterampilan dalam mengajar. Mutu dosen dengan demikian diukur dari pelaksanaan tugas dan tanggung jawabnya yang meliputi lima hal di atas, yakni: tugas pendidikan, penelitian dan pengembangan ilmu, pengabdian pada masyarakat, pembinaan civitas akademika serta tugas 
administrasi/manajemen. Kualitas dosen diukur dari sejauh mana dosen bersangkutan dalam menjalankan kelima tugas dan tanggung jawab tersebut dengan memperhatikan kriteria masing-masing tugas dan tanggung jawab itu sebagaimana yang dijelaskan di bawah ini.

Ketiga, proses pendikan yang berkualitas. Dalam hal tugas pendidikan, dosen yang berkualitas adalah dosen yang melaksanakan tanggung jawab pengajaran, bimbingan, dan latihan keterampilan bagi para mahasiswanya. Ada tiga faktor yang mempengaruhi proses pendidikan yang berkualitas, yakni mahasiswa, profesi, dan institusi.

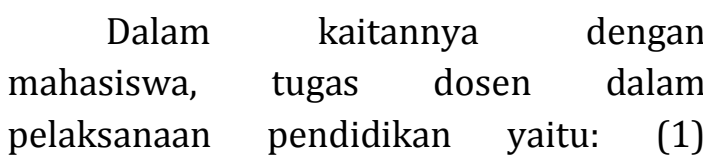

Melaksanakan tugas mengajar dengan memakai perencanaan bahan kuliah, persiapan perkuliahan, hadir di kelas sesuai jadwal, mengemukakan syaratsyarat perkuliahan secara jelas, serta memberi nilai secara objektif sesuai ketentuan lembaga; (2) Menyadari bahwa mahasiswa sebagai individu harus dihormati dan mempunyai hak-hak yang harus dilindungi. Hal ini menuntut adanya perhatian pada masalah-masalah akademik dan pribadi yang dihadapi mahasiswa dengan memberi nasehat, memperlakukan mereka dengan baik di kelas, menyimpan rahasia pribadi mahasiswa yang mereka kemukakan pada saat konsultasi; (3) Menyadari bahwa dosen adalah teladan bagi mahasiswa dan berpengaruh terhadap pembentukan sikap dan pemikiran mahasiswa. Oleh karena itu, harus senantiasa ditunjukan keteladanan kepada mahasiswa dalam hal kemampuan akademik, intelektualitas, integritas pribadi, dan etika profesi; (4) Menyadari bahwa dosen tidak dibenarkan menggunakan kedudukan dan pengaruhnya di kelas (perkuliahan) untuk menyampaikan materi dan masalah yang di luar lingkup mata kuliah dan di luar kompetensi profesinya.

Dalam hal tanggung jawab profesi, tugas dosen adalah: (1) Tanggung jawab untuk selalu mengikuti perkembangan ilmu pengetahuan dalam disiplin akademiknya, dengan membaca lektur yang baru atau berupa jurnal, dan mengikuti kegiatan ilmiah berupa diskusi atau seminar, mengenai bidang studinya; (2) Selalu berusaha meningkatkan keefektifan mengajar, mencari cara-cara baru dalam menyampaikan materi kuliah, memotivasi mahasiswa dan memperbaiki metode evaluasi prestasi mahasiswa; (3) Bertanggung jawab untuk ikut serta mengembangkan ilmu pengetahuan dalam bidang studinya melalui penelitian, analisis, dan penulisan secara kreatif serta menyajikan makalah pada kesempatan diskusi atau seminar; (4) Bertanggung jawab untuk membantu kolega dosen dan membantu lembaga dalam kegiatan pengembangan kurikulum, kegiatan ilmiah jurusan, Fakultas dan Universitas serta berpartisipasi di dalamnya, serta kegiatan kepanitiaan yang diselenggarakan oleh Jurusan, Fakultas dan sebagainya; (5) Bertanggung jawab untuk melindungi dan meningkatkan gengsi akademik dan profesi dosen antara lain dengan membantu merekrut dosen baru yang berkualitas, memberikan rekomendasi yang objektif dalam kenaikan jabatan akademik kolega dosen lain, merekomendasi dosen yang nyata-nyata tidak memiliki kemampuan akademik, tidak memiliki integritas pribadi, berkelakuan buruk dan sebagainya; (6) Bertanggung jawab untuk memberikan contoh menghormati hak orang lain untuk berbeda pendapat.

Sedangkan untuk tanggung jawab institusional, dikemukakan yaitu: (1) Selalu melaksanakan tugas kelembagaan 
dengan baik; (2) Menggunakan dana yang dipercayakan kepadanya dengan sebaikbaiknya sesuai dengan anggaran yang ditetapkan; (3) Selalu berusaha sesuai dengan kemampuan profesi dan kemampuan pribadinya untuk mencegah terjadinya kerugian finansial atau hal lain yang merugikan nama baik lembaga, baik secara legal maupun sosial; (4) Mencegah terjadinya penggunaan sumber dana dan daya untuk keuntungan dan kepentingan pribadi, seperti dalam proyek penelitian, proyek konsultasi, kecuali dengan izin khusus; (5) Memberikan dukungan yang baik pada kegiatan-kegiatan lembaga dengan berpartisipasi aktif di dalamnya; (6) Mempunyai komitmen yang mantap dalam pengembangan perpustakaan, laboratorium dan sebagainya; (7) Dalam menyampaikan ide pribadinya kepada masyarakat tidak mengatasnamakan lembaga, tapi secara tegas harus menyatakan sebagai cendekiawan atau warga negara.

Dalam kaitan dengan tugas pendidikan tersebut, dapat dikatakan bahwa penguasaan materi dan keterampilan teknis dalam proses belajar mengajar merupakan dua hal yang mutlak harus ada pada dosen. Melalui penguasaan materi dan keterampilan teknis mengajar pada dosen, pelaksanaan pengajaran yang mendidik dapat dilaksanakan. Pelaksanaan pengajaran ini menempati kedudukan sentral, sebab pada kegiatan ini terjadi titik temu antara pendidik dengan terdidik dalam tugas pelaksanaan misi pendidikan.

Kualitas membuat Rencana Pengajaran dilihat melalui lima kemampuan penampilan yakni (a) merencanakan pengorganisasian bahan pengajaran; (b) merencanakan pengelolaan kegiatan belajar mengajar; (c) merencanakan pengelolaan kelas; (d) merencanakan penggunaan media dan sumber pengajaran; dan e) merencanakan penilaian prestasi mahasiswa untuk kepentingan pengajaran.

Sementara itu, kualitas prosedur mengajar dilihat melalui tujuh kemampuan penampilan, yakni (1) menggunakan metode, media dan bahan latihan yang sesuai dengan tujuan pengajaran; (2) berkomunikasi dengan mahasiswa; (3) mendemonstrasikan khazanah metode mengajar; (4) mendorong dan melaksanakan keterlibatan mahasiswa dalam pengajaran; (5) mendemonstrasikan penguasaan mata pelajaran dan relevansinya; (6) mengorganisasi waktu, ruang, bahan, dan perlengkapan pengajaran; dan (7) melaksanakan evaluasi pencapaian mahasiswa dalam proses belajar mengajar. Sedangkan kualitas "hubungan antar pribadi" dilihat melalui empat kemampuan penampilan yakni (a) membantu mengembangkan sikap positif pada diri mahasiswa; (b) bersikap terbuka dan luwes terhadap mahasiswa dan orang lain; (c) menampilkan kegairahan dan kesungguhan dalam kegiatan belajar mengajar; dan (d) mengelola interaksi dalam kelas.

Dalam hubungannya dengan pelaksanaan pendidikan mahasiswa berupa pendidikan dan pengajaran, penelitian, dan pengabdian kepada masyarakat dalam rangka pendidikan kepada mahasiswa, kualitas dosen berdasarkan referensi SK. Menpan No. 59/1987 diklasifikasi pada tiga tingkat kewenangan yang terkait dengan jabatan tenaga pengajar, yakni dosen yang sudah memiliki kewenangan melaksanakan tugas secara mandiri (M), dosen yang kewenangannya berdasarkan tanggung jawab tenaga pengajar yang masih senior yang sudah memiliki wewenang dan tanggung jawab penuh dalam bidang 
tugasnya (D) serta dosen yang kewenangannya hanya membantu pengajar yang lebih senior (B). Secara beruntun diasumsikan bahwa dosen dalam kewenangan $\mathrm{M}$ lebih berkualitas dibanding dengan kewenangan D. demikian juga antara kewenangan $\mathrm{D}$ dengan kewenangan $\mathrm{B}$.

Keempat, kualitas tugas penelitian. Penelitian yang berkualitas memenuhi syarat dari beberapa aspek penelitian, yakni permasalahan dengan latar belakangnya, tujuan yang hendak dicapai, kerangka pemikiran, premis dan hipotesis atau pertanyaan penelitian, metode, hasil serta kesimpulan penelitian. Dari masalah, landasan teori, metode, kesimpulan, dan saran harus kesesuaian (Nasition, 1982: 175). Kualitas penelitian berkaitan dengan kejelasan tema sentral, mekanisme proses munculnya masalah, identifikasi masalah, tingkat kepentingan atau kegunaan permasalahan bagi kehidupan masyarakat, peluang fakta untuk diobservasi secara objektif, sehingga menghasilkan data yang cukup dan valid, keluasan dampak terhadap aspek-aspek kehidupan lain, kemungkinan pelaksanaan kegiatan serta tinggi rendahnya urgensi pemecahan masalah (Atmadilaga. 1989:33). Secara lebih rinci Stepheen Isaac dan William B. Machel (1989:33), membagi penilaian permasalahan dalam penelitian ini pada dua besaran pertimbangan, yakni pertimbangan pribadi (personal consideration) dan pertimbangan sosial (social consideration). Pada sisi lain, Nasution mempersyaratkan lima permasalahan penelitian, yakni (a) masalah itu hendaknya bertalian dengan konsepkonsep yang pokok atau hubungan antara konsep-konsep yang pokok; (b) masalah itu hendaknya mengembangkan atau memperluas cara-cara men-test teori; (c) masalah itu memberi sumbangan kepada pengembangan metodologi penelitian dengan menemukan alat, teknik atau metode baru; (d) masalah itu hendaknya memanfaatkan konsep-konsep, teori atau data dan teknik dari disiplin-disiplin ilmu yang berlainan; (e) masalah itu hendaknya dituangkan dalam desain yang cermat dengan uraian yang teliti mengenai variabel-variabelnya serta menggunakan metode yang paling serasi (Nasution, 1982:24). Sedangkan perihal tujuan atau output penelitian, keberkualitasan terletak pada kejelasan identifikasi tujuan tersebut. Terdapat banyak kemungkinan bentuk output, yang pada prinsipnya terdapat satu atau lebih konsep-konsep. Mungkin berupa rumusan-rumusan kesimpulan atas kecenderungan umum, generalisasi, atau ketentuan suatu eksistensi, esensi, sifat-sifat khusus dan umum, hubungan suatu proses perilaku, tetapi juga dapat berupa suatu benda/alat atau suatu sistem, atau berupa kesimpulan sebagai hipotesis, gagasan prinsip atau dugaan teoritis. Hal ini erat kaitannya dengan metode. Diperlukan konsistensi metodologis, sehingga terdapat benang merah yang terentang lurus antara paradigma, kisi-kisi dan instrumen data, selain cara pengujian akurasi data dan verifikasinya.

Kelima, kualitas tugas pengabdian pada masyarakat. Pengabdian pada masyarakat merupakan kegiatan yang menghubungkan hasil penelitian dan penguasaan disiplin ilmu dalam bidang pendidikan di satu sisi, dengan peningkatan kualitas pendidikan dan pengembangan masalah penelitian pada sisi lain. Namun demikian, kegiatan pengabdian pada masyarakat di perguruan tinggi, difungsikan dan diarahkan juga untuk menunjang pembangunan di berbagai lapisan masyarakat. Berdasarkan fungsi dan sasaran di atas, tolok ukur kualitas 
pengabdian pada masyarakat tidak hanya berkaitan dengan keilmuan saja, namun berkaitan secara kompleks dengan kelembagaan dan kemasyarakatan. Hal ini berarti menyangkut masalah pengadministrasian kegiatan warga kampus di luar kampus.

Berbagai aspek pengukuran kualitas kegiatan pengabdian pada masyarakat adalah (a) kegiatan atas nama perguruan tinggi; (b) usaha bersama antara perguruan tinggi dengan masyarakat tempat kegiatan tersebut dilaksanakan; (c) seimbang dengan kegiatan pendidikan dan penelitian; (d) atas inisiatif subjek pelaksanaan kegiatan; (e) bermanfaat bagi masyarakat tempat kegiatan dilakukan; (f) menunjang pembangunan di satu segi dan menunjang pengembangan ilmu pada sisi lain; dan (g) merupakan pengalaman ilmiah dari ilmu yang dikaji, sehingga merupakan kegiatan yang efisien dan efektif.

Keenam, Kualitas Tugas Pembimbingan. Tugas pembimbingan terdiri atas dua macam, yakni (a) bimbingan akademik dan (b) bimbingan penulisan skripsi. Pada bimbingan akademik, ciri keberkualitasannya terletak pada kemampuan menyalurkan potensi akademik, mahasiswa, sehingga mahasiswa dapat mengikuti ketentuanketentuan akademik dengan tetap mengarah pada tujuan studi di perguruan tingginya. Tugas pembimbing akademik adalah:

1. Mengusahakan agar setiap mahasiswa yang berada di bawah tanggung jawab seorang dosen memperoleh pengarahan yang tepat dalam menyusun program dan beban belajarnya, dan dalam memilih mata kuliah yang akan diambilnya;

2. Memberikan kesempatan kepada mahasiswa untuk membicarakan masalah-masalah yang dialaminya, khususnya yang berkenaan dengan pendidikan itu;

3. Membantu mahasiswa agar dapat mengembangkan sikap dan kebiasaan belajar yang baik.

Dalam kaitan ini, etika yang dikemukakan oleh Kenneth dijelaskan bahwa sebagai dosen yang bertanggung jawab, maka dosen diharuskan (a) memperlakukan mahasiswa dengan baik; (b) menyimpan rahasia pribadi mahasiswa yang mereka kemukakan saat mereka berkonsultasi; (c) tidak menyalahkan kedudukan dan pengaruhnya untuk masalah-masalah di luar kompetisi profesinya. Sementara tugas pembimbingan skripsi, tesis, dan disertasi diarahkan untuk memberikan kebebasan mahasiswa mengekpresikan potensi keilmuannya sambil tetap berada dalam jalur disiplin dan metode penelitian yang sudah lazim (Kenneth, 2008:32).

Ketujuh, Kualitas Tugas Pelaksanaan Administrasi. Terdapat tiga macam tugas dalam bagian ini, yakni struktural, kepanitiaan, dan administrasi dosen. Berdasarkan tugas dan tanggung jawab serta aspek-aspek yang harus diperhatikan dalam kegiatan pendidikan, penelitian, dan pengabdian kepada masyarakat, dosen yang berkualitas adalah dosen yang menguasai, mengikuti perkembangan, mampu mengembangkan serta bertanggung jawab terhadap disiplin ilmunya, memiliki kemampuan berinteraksi dengan mahasiswa secara profesional, menghormati dan melindungi hak-hak mahasiswa, menjadi teladan dalam sikap dan pemikiran, berkemampuan menyusun kurikulum yang relevan, efektif dan efisien, memberikan informasi yang luas, dalam dan mutakhir menciptakan suasana akademik yang kondusif bagi pengembangan mahasiswa, membuat sistem penilaian yang objektif serta 
pemantauan dan evaluasi yang teratur, sebagai kegiatan yang berlangsung berhubungan, baik dengan "transfer of knowledge" maupun pengembangan "scientific attitude" mahasiswa.

Selain itu, juga dapat dilihat dari klasifikasi pendidikan (S2/S3) dan jenjang jabatan akademiknya. pengelolaan mutu dosen dapat dilakukan melalui peningkatan pendidikan ke strata yang lebih tinggi di PT negeri maupun swasta terbaik di dalam maupun di luar negeri secara bertahap dan berencana. Kemudian juga dapat dilakukan melalui meningkatkan kegiatan-kegiatan seminar (lokal, regional, dan nasional), simposium, diskusi, serta penataran-penataran dan lokakarya, baik di fakultas dan universitas sendiri, maupun di perguruan tinggi terkemuka di tanah air. Serta meningkatkan kegiatan kerjasama dengan dinas-dinas, dunia usaha dan dunia industri dalam kaitannya dengan program keterkaitan dan kesepadanan sebagai penambah wawasan dan cara berpikir serta keterampilan bagi dosen.

\section{Tuntutan Dunia Kerja}

Tuntutan dunia kerja yang semakin berat memunculkan tugas baru bagi dunia pendidikan termasuk perguruan tinggi terutama dalam membekali peserta didik dan mahasiswa dengan kemampuan profesional. Data dari info kerja Jawa Timur menujukkan bahwa masalah ketenagakerjaan di Indonesia sampai detik ini masih diwarnai dengan tingkat pertumbuhan angkatan kerja yang tinggi. Di sisi lain, kesempatan kerja yang tersedia di dalam negeri belum dapat menyerap seluruh angkatan kerja yang ada. Hal ini disebabkan oleh beberapa faktor yang terkait, antara lain ekonomi, demografi, sosial budaya termasuk masih tingginya tingkat kelahiran yang setiap tahun mencapai lima juta orang (talk show di TVRI Kepala BKKBN minggu II Maret 2013).

Berdasarkan data yang dirilis oleh BPS Jawa Timur diketahui data bahwa posisi bulan Agustus 2012 jumlah angkatan kerja sebesar 19.901.558 orang, bila dibandingkan dengan tahun 2011 bulan yang sama mengalami kenaikan sebesar 139.672 ribu orang, meskipun peningkatan tersebut tidak signifikan terhadap peningkatan pekerjaan, namun dapat menggambarkan kompetisi angkatan kerja semakin ketat. Seiring dengan pertumbuhan angkatan kerja yang signifikan, maka Tingkat Partisipasi Angkatan Kerja (TPAK) juga mengalami peningkatan juga. Hal ini disebabkan tuntuan kebutuhan hidup yang semakin tinggi, contohnya tenaga kerja wanita yang semula hanya mengasuh anaknya, begitu anaknya sudah masuk sekolah maka mereka memutuskan untuk masuk ke pasar kerja (www.infokerja-jatim.com).

Indikator utama sebagai indikasi keberhasilan dalam penanganan pengangguran adalah terjadinya penurunan Tingkat Pengangguran Terbuka (TPT) yang merupakan perbandingan antara jumlah penganggur dengan jumlah angkatan kerja yang ada. TPT di Jawa Timur masih cukup tinggi, yakni sebesar $4,12 \%$ atau 819.563 orang. Pada tahun 2013, Pemerintah Provinsi Jawa Timur optimis dan bertekad untuk menurunkan TPT hingga 3,5 \%. Untuk mewujudkan keinginan itu tentunya perlu upaya-upaya keras dalam menekan jumlah penganggur dan kemiskinan yang ada, khususnya dengan menciptakan dan mendayagunakanpekerjaan-pekerjaan di sektor informal. Selama tiga tahun terakhir (data BPS Jatim), jumlah pekerja informal semakin menurun dan bergeser pada pekerjaan formal. Hal ini diduga karena sektor informal belum didukung oleh sumber daya manusia yang tinggi dan 
sumber daya yang kuat. Kita sadar bahwa masyarakat penganggur secara umum masih mendambakan pekerjaan yang bersifat formal, yang menurut pemahaman mereka kerja di sektor formal lebih bergengsi dan pasti (www.infokerjajatim.com).

Mengapa perluasan kerja informal perlu dikembangkan? ada beberapa alasan yang mendasari perlunya sektor informal diberdayakan, antara lain masih banyaknya jumlah angkatan kerja muda produktif umur 15-34th yang terus bertambah, jumlah angkatan kerja muda berdasar pendidikan (SLTP-S1) terus bertambah, sektor formal belum mampu menyerap seluruhnya angkatan kerja yang ada, belum dioptimalkan pemanfaatan SDA dan SDM yang ada untuk mendorong peran aktif masyarakat dan pengembangan sektor produktif, angkatan kerja muda memiliki potensi bagus, sektor informal membutuhkan modal relatif tidak besar, fleksibel, menyerap lapangan kerja terbanyak dan tahan krisis, mendorong terbentuknya cluster-cluster sentra ekonomi produktif berdasar potensi SDA dan SDM, sebagaimana telah dicanangkan oleh Menakertrans RI di Desa Tutul, Kec. Balung Kab. Jember tanggal 19 Pebruari 2013, bahwa desa tersebut yang Kepala Desanya seorang wanita, merupakan Desa Produktif Tingkat Nasional, yang warganya tidak ada yang menganggur, yang hampir setengah penduduknya yang berjumlah 10.000 orang bekerja mandiri di bidang kerajinan dan pendapatan perkapita mencapai Rp. 5,5 juta perbulan.

Maka tak terelakkan lagi, perguruan tinggi dengan berbagai kekuatan dan peluang yang dimiliki mengemban tugas penting dalam mendorong kesempatan kerja. Dalam rangka itu dapat digunakan pendekatan management strategyc dengan menyusun visi, misi yang specific dan jelas, melakukan analisis SWOT, Strength (kekuatan), Weakness (kelemahan), Opportunity (kesempatan/peluang) dan Threat (ancaman) serta menyusun tujuan dan target objektif yang jelas, baik ukuran waktu maupun pendekatan keberhasilan menyusun strategi pengembangan entrepreneurship yang sesuai, mengimplementasikan strategi, mengatasi kendala, mengevaluasi kerja dan melakukan tindakan perbaikan. Mengingat perguruan tinggi Indonesia yang masuk peringkat 50 besar Asia baru UGM, ITB, UI, itupun masih di atas peringkat 10.

\section{Sarana-Prasarana Pendidikan}

Pendukung

Para pakar pendidikan seringkali menegaskan bahwa guru/dosen merupakan sumberdaya manusia yang sangat menentukan keberhasilan program pendidikan. Guru/dosen merupakan unsur manusiawi yang memiliki hubungan sangat dekat dengan anak didik dalam pelaksanaan pendidikan sehari-hari. Menurut mereka, apapun yang telah dilakukan untuk meningkatkan mutu pendidikan tidak mungkin tanpa ada peningkatan kualitas performa guru/dosennya. Oleh karena itu, menurut mereka, peningkatan mutu performa guru/dosen mutlak dilakukan secara terus menerus dalam rangka peningkatan mutu pendidikan.

Penegasan di atas, menurut Bafadhal, mengisyaratkan betapa pentingnya keberadaan dosen yang mampu mengelola proses belajar mengajar di Perguruan Tinggi. Namun, penegasan di atas tidak berati bahwa keberadaan unsur-unsur lain tidak begitu penting bagi peningkatan mutu pendidikan (Bafadhal, 2004: v). Gorton di dalam salah satu bukunya menegaskan bahwa "the physical environment in which we work can and does influence what we do 
and ho we feel" (Gorton, 1976). Dengan demikian, pembinaan kemampuan guru/dosen itu memang diperlukan dalam rangka peningkatan mutu. Namun dalam rangka itu pula, sekolah atau Perguruan Tinggi perlu adanya fasilitas atau sarana prasarana yang menunjang proses belajar mengajar untuk dapat meningkatkan mutu lembaga.

Untuk menghasilkan kualitas tenaga lulusan perguruan tinggi, maka harus bekerja sama dengan pihak dunia usaha sebagai penyerap dan pemakai tenaga lulusan perguruan tinggi $\mathrm{Hal}$ ini dapat dilakukan dengan melibatkan unsur mahasiswa, alumni, dan perusahaanperusahaan yang mewakili dunia usaha, untuk memberikan masukan yang berguna demi menghasilkan lulusan perguruan tinggi yang diharapkan mampu berkiprah di era globalisasi. Perlu perbaikan terhadap kurikulum dengan menambahkan program-program baru seperti: penguasaan bahasa internasional, teknologi komputer, program magang, dan etika.

Laboratorium sebagai ajang latih dan praktek mahasiswa perlu dilengkapi dengan fasilitas yang cukup serta program pelatihannya harus disesuaikan dengan perkembangan dunia industri dan jasa. Sedangkan perpustakaan sebagai jantungnya perguruan tinggi perlu diperkaya dan dilengkapi dengan berbagai jurnal dan literatur yang terbaru. Demikian pula gedung atau ruang perkuliahan serta perlengkapannya sebagai penunjang proses pendidikan sangat perlu mendapat perhatian dari segi kebersihan, keindahan serta kenyamanannya.

\section{Penutup}

Perguruan tinggi perlu mendorong upaya peningkatan kualifikasi tenaga dosen dengan pendidikan lanjutan atau kursus dengan fasilitas yang memadai agar kualitas sumber daya dapat ditingkatkan, sehingga secara otomatis akan mendorong peningkatan mutu pendididkan di PT. Tempat kerja menuntut seseorang yang tidak hanya memiliki kemampuan berfikir secara baik, tetapi juga keterampilan yang diperlukan dalam menyelesaikan setiap tugas. Seringkali lulusan pendidikan tinggi tidak memiliki kemampuan yang sesuai dengan harapakan dunia kerja. Sehingga tuntutan terhadap mutu pendidikan yang terus ditingkatkan sebagai upaya untuk menciptakan output dan outcomes yang berkualitas dan siap terjun ke pasar kerja (workplace), serta untuk memenuhi standar atau ketentuan akreditasi. Output yang dihasilkan tentunya berdasarkan suatu proses yang matang dan didukung oleh input yang baik pula, sehingga PT pada akhirnya akan mampu memenuhi kebutuhan dan tuntutan masyarakat sesuai dengan konsep link and match agar mampu meminimalisir gap antara PT dengan dunia kerja atau pengguna lulusan.

\section{DAFTAR PUSTAKA}

Atmadilaga, Didi. 1989. Buku Pintar Penulisa Karya Ilmiah. Tidak diterbitkan

Bafadhal, Ibrahim. 2004. Manajemen Perlengkapan Sekolah. Bumi Aksara: Jakarta.

Burnham, John West. 1997. Managing Quality in School: Effective Strategies for Quality Based School Improvement. London: Prantice Hall.

Ciptono, Fandy dan Anastasia Diana, 2003. Total Quality Management. Andi Offset: Yogyakarta.

Gorton, Richard. A. 1976. School Administration. Wm. C. Brown Company: USA. 
G. Gellin Armistead, 1999. Customer Service and Support. PT Gramdia: Jakarta.

Heryanto, Eko dan BN Mabnun, 1993. Pengendalian Mutu Terpadu. Pustakan Binaman Pressindo. Gramedia: Jakarta.

Isaac, Stepheen dan Wiliiam B. Machel, 1989. Naturalistic Inquiry. FPS IKIP: Bandung.

Murgatroyd, Stephenand Colin Morgan, 1994. Total Quality Management and The School. Open University Press: Buckingham-Philadelphia.

Nasution, 1982. Berbagai Pendekatan dalam Proses Belajar Mengajar. Bina Aksara Bandung.

Soetjipto, Bumi W., dkk, 2002. Paradigma Baru Manajemen Sumberdaya Manusia. Amara Book: Yogayakarta.

Saksono, Slamet. 1997. Administrasi Kepegawaian. Kanisius: Yogyakarta.

Tim Dosen UGM, 2005. Lokakarya Sosialisasi Jaminan Mutu Pendidikan Tinggi. Yogyakarta.

Thurow, 1999. Creating Wealth. Nicholas Brealey Publishing: London. 